\title{
SEXUAL VIOLENCE AND NEW FORMS OF RELIGIOUS TRADITIONALISM IN THE CROATIAN POST-CONFLICT CONTEXT
}

\author{
UDC 343.551-053.2(497.5)
}

\author{
Jana Kujundžić \\ Department of Sociology, University of Essex, United Kingdom
}

\begin{abstract}
This paper will focus on sexual violence and new forms of religious traditionalism emerging in the Croatian political context, and their interpretation of the term "gender". The methodological framework of Critical Discourse Analysis will be used to investigate the debates surrounding the ratification of the Istanbul Convention (Convention on Preventing and Combating Violence against Women and Domestic Violence) in Croatia in 2018. Religious conservative organisations started to frequently utilize the term "gender ideology" to create fear, confusion and moral panic in the public discourse in connection to the ratification. According to their interpretations, "gender ideology" in the Istanbul Convention was "smuggled in" to destroy the traditional Croatian Catholic heterosexual family by enabling children to choose their own gender. Croatia has undergone significant changes since the dissolution of Yugoslavia in the 1990s, dismissing its socialist legacy with the support of the Catholic Church and its staunch anti-communist rhetoric which seeks to undo any progress in terms of gender equality achieved during socialism. Researching sexual violence from the intersectional feminist framework poses a challenge in a climate where the conservative discourse has hijacked any discussion on sexual violence in the public sphere by contesting the term gender itself and making it a questioned category of social analysis. Even though Croatia has ratified the Istanbul Convention in April 2018, the government has issued an "interpretative statement" further legitimizing the term "gender ideology."
\end{abstract}

Key words: sexual violence, religious traditionalism, gender ideology

\section{NEW RELIGIOUS MOVEMENTS}

Alongside the rising right-wing populism in Europe, religious fundamentalists have been organizing new religious movements across countries. Anti-gender strategies started developing a couple of decades ago with the Vatican`s reaction to the 1994 UN Conference

Received May $17^{\text {th }}, 2019 /$ Accepted August $13^{\text {th }}, 2019$

Corresponding author: Jana Kujundžić, MA, PhD Candidate in Criminology, Department of Sociology, University of Essex, Wivenhoe Park, Colchester CO4 3SQ, United Kingdom; E-mail: j.kujundzic@essex.ac.uk 
on Population and Development in Cairo and the 1995 Beijing World Conference on Women. Paternotte \& Kuhar (2017) map out the history of the notion of "gender ideology", which emerged in the mid-1990s as an answer to the concepts of sexual and reproductive rights in the UN rights system. The main concern for the Catholic Church was that proliferation of sexual and reproductive rights would open the way for deterioration of the traditional heterosexual family with international acceptance of abortion and same-sex marriage. The negative term "gender ideology" became a means of action in the global Catholic strategy but it has also spread beyond Catholic circles (Paternotte \& Kuhar, 2017: 12).

In fighting the privatization of religion, the Church mobilized lay believers to publicly declare their faith by mimicking progressive movements, such as the Pride Parade, and to get organized by using new technologies, especially social networks. The right-wing wave reinforced anti-gender campaigns since "gender ideology" functions as symbolic glue against a common enemy: the left, feminists, LGBT activists, minorities, etc. (Kovats \& Poim, 2015: 34). Also, as an empty signifier, it can be used to serve any means of a threat to the "natural" order. The economic crisis and austerity measures in many countries enabled anti-gender protests by providing an outlet to the frustration with the corrupt elites and scapegoating the minorities as culprits for the crisis. These conservative movements present themselves as the "silent majority", as opposed to corrupt international elites who are trying to impose perversion on the normal people. Their populist strategy involves the use of referendums, as seen in Slovenia, Croatia, Slovakia and Romania.

In the context of anti-gender movements, Croatia shares some similarities with other European countries but also features some specific differences. The post-conflict context of Croatia in the 1990s was characterised by a state-building project which positioned Catholicism as the core element of Croatian national identity construction. During the war, Croatia was supported by the Catholic Church, and the Vatican was among the first states to recognize Croatian independence. After the end of the war, the Vatican Agreements were signed between the Roman Catholic Church and the Republic of Croatia. According to the last population census in $2011^{1}, 86.28 \%$ of the Croatian population identifies as Roman Catholic. The Roman Catholic Church has a powerful influence on the public discourse in Croatia, including the support of most parties. The Catholic Church has been very active in Croatian social and political life since the 1990s by pushing for various actions which promote its values (such as: the non-working Sunday; punishment for the crimes committed in the socialist era; introducing religious education at all institutional levels of education (in preschools, primary and secondary schools, and higher education institutions); protection of marriage as the union of "a man and a woman"; opposing LGBT rights, abortion, euthanasia, natural methods of family planning and the treatment of infertility; and opposing artificial birth control methods (Galić, 2018: 214). The war period in the 1990s was also a shift from state socialism to capitalism. The privatization enabled the creation of so-called "new elite", consisting of former company directors (who bought socially owned enterprises), state banks and a small number of entrepreneurs, which caused public indignation (Čengić, 1996: 550). Women were the first to be laid off during the transition period and they went back to their traditional roles of home makers (Kamenov \& Galić, 2011: 19). Since gender equality was a strong ideological point in the former Yugoslavia, conservative actors connected to the Catholic Church, and the Church itself, tried to "bring back" the traditional Catholic values by destroying the socialist legacy of gender equality

\footnotetext{
${ }^{1}$ Croatian Central Bureau of Statistics, population census of 2011, www.dzs.hr/
} 
and, in consequence, devaluing women`s lives and social conditions. In the Socialist Republic of Croatia before the 1990s, women constituted $16 \%$ to $18 \%$ of representatives in the government; in 1990s, they constituted only $4.7 \%$ of representatives in the Croatian parliament (Kamenov \& Galić, 2011: 17). According to the last available data ${ }^{2}$ for the year 2016, women constituted $12.6 \%$ representatives in the Croatian parliament.

The retraditionalization, signifying the post-1990s period in Croatia, also included attacks on the reproductive rights, as seen in the recent request for rewriting the abortion law from 1974 which guaranteed women`s right of free choice in family planning. One of the new conservative religious organisations ("Vigilare") drafted a new legislative proposal on abortion legislation, requesting a total abortion ban and organizing " 28 days of prayers for the unborn children" in front of hospitals, which was inconceivable in former Yugoslavia. Many doctors have proclaimed their religious conscience exemption as a reason for not performing abortions in public hospitals, but many of them perform abortions in their private practices (Mrvoš Pavić, 2017). The timing went hand in hand with the current wave of right-wing populism taking place in Europe and in Croatia. The Church`s collective identity building and ardent anti-communism were perfectly aligned with the politics of the Croatian ruling party, Croatian Democratic Union (HDZ). This issue will be addressed later in this paper.

New conservative religious movements first appeared in the public spotlight in 2013 when the religious organization " $U$ ime obitelji" ("In the name of the family"), supported by the Catholic Church, prompted the call for a referendum to define marriage as a union between a man and a woman in the Croatian Constitution. What is interesting is that this initiative came as a response to the legalizations of same-sex marriages in Great Britain and France even though such proposal was not on any political agenda in Croatia. This was the first referendum where citizens were voting directly on a constitutional provision in Croatia. The votes for the referendum were collected in front of the churches and the ambiguous political slogans, such as: "Let's protect the traditional family", drew enough votes for the referendum to be held. Despite the low turnout of voters, ${ }^{3}$, the referendum passed with the majority vote for the provision. Nevertheless, the Civil Partnership Act was passed the same year, enabling same-sex partners to obtain their rights through the civil union but without the right to adopt. Currently, there is a dispute over the Foster Parenting Act which excludes same-sex couples.

\section{OPPOSING THE ISTANBUL CONVENTION}

The Church has lobbied against the ratification of the Istanbul Convention, especially bothered by the positioning of domestic violence as gender-based violence which highlights the historical oppression of women as well as the social construction of gender (Pavičić, 2017). The connection between new conservative religious groups in Croatia, such as $U$ ime obitelji (In the name of the family) and Vigilare, and issues of sexual violence can be seen in their involvement with the legal system in which they try to imprint their "values", presenting themselves as a silent majority as opposed to the corrupt elites (e.g. EU, Soros, Free Masons, Jews, and feminists). This follows similar trends of retraditionalisation and strengthening of

\footnotetext{
${ }^{2}$ Croatian Central Bureau of Statistics, Women and Men in Croatia, 2018, www.dzs.hr/

${ }^{3}$ According to the Croatian State Electoral Committee, only $37.40 \%$ of the Croatian population voted in the referendum.
} 
the right-wing and religious organizations in the Eastern and Central European countries (Kovats, 2017: 55). Although the Convention was ratified in April 2018, misinformation about the Convection and rallying cries against it kept spreading across newspapers and social media in Croatia. The term "gender ideology" was used as a way of demonizing gender equality ideas and positioning them as a threat to the traditional Croatian Catholic family. This term was not specific just to Croatia but was used in countries across the world. It is substantiated by the explanations of Paternotte and Kuhar (2017: 14) about travelling strategies of the anti-gender initiatives and how certain anti-gender campaigns travelled from the U.S to Eastern and Central Europe. Likewise, since these organizations are backed up by U.S financially and ideologically, some of the discourses were imported from the U.S (Pavic, 2018), such as the fear of men deciding to become women and enter women's restrooms. Recent journalistic research has shown that Vigilare is also connected to the Polish ultraconservative organisations (Brakus, 2018). Supporters of such organizations and their activities are members of the clergy, war veterans, far-right politicians and their supporters. The religiousness and traditionalism in their discourse are usually coupled with nationalism, anti-communism and chauvinism, which will be explicated further on in this paper.

The issue of relevance for this research is how the term "gender" is redefined and how the invented negative term "gender ideology" is used to manipulate the Croatian public by drawing away the attention from the victims of sexual violence and the problems within the legal system. The meaning of "gender ideology" has changed over the years to serve a particular agenda. For example, in 2016, it was used to obstruct the introduction of health care and sexual education in Croatian schools by claiming that "gender ideology" will be introduced in schools to normalise homosexuality and make children gay. In 2017, during the process of public debate on the issue of the ratification of the Istanbul Convention, it was claimed that "gender ideology" was smuggled in the Convention and it would allow children to choose their own gender. The political homophobia became political transphobia, continuing its scapegoating of the LGBT population.

On the rare occasions when sexual violence was discussed, the public discourse was plagued by rape myths, stereotypical views of gender roles and victim-blaming. Rape myths refer to a range of common beliefs and convictions surrounding the issue of rape: that rapes are only committed by strangers in dark alleys, that the victim did something to provoke the rapist and thus contributed to her/his own victimization, that there is no such thing as a marital rape, and that women often falsely report rape.

The discourse of "gender ideology" was looming in all the debates surrounding the ratification of the Istanbul Convention. There were even some claims that Croatia does not need such a convention since we have all of its mechanisms already prescribed in our laws (Kovačević Barišić, 2018). Claiming that Croatia does not need such a convention can be seen as taking the easy way out of the debate. The Istanbul Convention explains the gender-based violence as the basis for its protective mechanisms and educational reforms, which is the term that "triggered" the conservative uproar. But this uproar came at the specific time since the Convention was signed by Croatia in 2013 and, back then, there was no such outcry over the term "gender".

\subsection{Balkanism, victimhood and sovereignty}

In 2018, the initiative called "Croatian against the Istanbul Convention" organized a demonstration against the Istanbul Convention, gathering around 5,000 protesters (as 
estimated by the police) while the organizers claimed there were 70,000 protesters present. To unpack some of the discourses being used around the ratification, the author of this article draws upon the critical discourse analysis (CDA), which can be defined as a "critical perspective on unequal social arrangements sustained through language use, with the goals of social transformation and emancipation" (Lazar, 2005: 1). The CDA is concerned with uncovering the hidden or embedded power relations in discursive practices, the establishment of dominance and discrepancy in discourse, the ideological background of discourse and connection of discourse with societal changes (Fairclough, 1995, 2001, 2003; T. A. van Dijk, 1993). The symbols and messages of the protests were filled with nationalistic slogans and speeches calling to "preserve Croatia's sovereignty and values" and proclaiming that "Europe had no mercy while there were killings in Croatia and now [it] wants to conquer us with the velvetiness of the Convention" (N.C., 2018).

In this sense, the last sentence evokes a powerful imagery of the war in the 1990s and the killings during the war. The official ${ }^{4}$ Croatian nationalistic narrative (such as the "The Homeland War" and in some cases "Greater Serbian Aggression on Croatia") refers to the wartime period. The discourse used in the statement clearly points to the killings of Croatian victims in this war (as opposed to the Serbian or Bosnian ones, or victims of any other ethnicity), further bolstering the idea of innocence and victimhood. Furthermore, there is a clear power relation between Croatia and Europe since Europe is positioned as "having no mercy" to prevent the killings in Croatia and now wants to conquer with a convention. This discourse of resisting so-called colonization from the European Union is not new and it was seen in the 2012 protests to Croatia entering the EU; ${ }^{5}$ but, in that case, the right-wing party HDZ strongly supported the accession process; as the ruling parliamentary party, it influenced the change of the constitutional provision ${ }^{6}$ on the referendum rules for fear that the idea of joining the EU would not be supported by a sufficient number of voters. The main narrative used by politicians back then was the idea that Croatia never really belonged to the Western Balkans and that it would finally come to its rightful place by entering the EU. A similar narrative was expressed during the ratification of the Convention, as the current Prime Minister Andrej Plenković, who played the crucial role in the ratification, opposed several members of his own HDZ party and the bishops of the Catholic Church. Plenković distanced himself from the "backward" (Balkan) far-right conservatives and presented himself as a moderate (Pro-European) and right-wing centrist, thus pleasing the voters from the center of the political spectrum and winning over some of the voters from the disappointed centre left.

Here, the author stresses the interplay between the Balkan/European dichotomy and self-colonizing discourse underpinning both identities, viewing the Balkan as backwards (Todorova, 2009: 288) and (Western) Europe as progressive, making them at the same time "floating signifiers". For Hall (1999), a floating signifier refers to a term without a fixed meaning, and he used the example of the race to illustrate it. The skin color does not have a fixed meaning; its significance and social status changes depend on the different cultures (Hall, 1999: 8). In this context, the floating signifiers are the Balkan and the EU. For conservative, anti-gender and Catholic press, the European Union and its "liberal" and

\footnotetext{
${ }^{4}$ The "official" narrative implies that the terms are used in the official historical records, history schoolbooks, laws and by-laws.

${ }^{5}$ RTV B92 (January 2012). Zagreb: Protest against the EU, https://www.youtube.com/watch?v=dViCrTaTpBc/

${ }^{6}$ The HDZ abolished the condition that referendum is valid if there is absolute majority of votes $(50 \%$ of the total number of voters plus one voter)
} 
decadent values will erode the traditional Croatian catholic heterosexual families, while the liberal leftist press places emphasis on moving away from the savage Balkan towards the European civility and progress. In the same way, the term "Balkan", usually used in a derogative way, can be used as an excuse and justification of violence of men based on their Balkan masculinity and their "Balkan blood and passion" (Luketic, 2013: 24). The anti-EU rhetoric of conservative religious actors and the Catholic Church serves as a narrative against the privatization of religion by engaging lay believers to publicly proclaim their faith by mimicking progressive movements (such as the Pride Parade) and by using new technologies to get organized, especially social media networks.

\subsection{Against equality and the patriarchal bargain}

Several Catholic priests issued statements to the press (Golemac, 2016) that "women are being disobedient by always asking for their rights while it is God`s truth that men come first while women come second. One bishop proclaimed that "Jesus Christ is the best protection against domestic violence" (B, 2018). Even though the language of the clergy and the anti-gender movements is focused on morality, family and culture, the involvement of such rhetoric in the Istanbul Convention ratification process was a political one (Korolczuk \& Graff, 2018: 799). However, the irony is that many Catholic shelters for battered women are entitled to obtain funding under the Convention, but none of them issued a statement saying they will refuse the money.

Both the clergy and lay believers instrumental in organizing and speaking against the Convention perceive or rather construct gender as a threat to the sex binary and naturalise different social roles for men and women. Their discourse relies on the exemplification of the binary of male-female difference and perpetuates patriarchal family as natural and "pre-political" (Peterson, 1999: 40).

Numerous women are visible in the new religious movement, even profiling themselves as leaders, such as Željka Markić from the conservative organisation " $U$ ime obitelj" (In the name of the family) and Rozalija Bartolić, from the Association of Widows of Croatian War Veterans and the spokesperson for the intiative "Croatia against the Istanbul Convention." At first glance, their activities might be perceived as being detrimental to their own interests as women in Croatia; but, as Kandiyoti (1988) explains, in an attempt to maximize their own strength and potential, women reinstate the patriarchal bargain; they adhere to and comply with patriarchal norms, adopting gender roles that are harmful to all women. In that sense, antifeminism expressed by these women aligns them with men, which makes them worthy of protection, and also provides scapegoats (feminists) on whom men can pinpoint their current alienation and dissatisfaction (Kandiyoti, 1988: 284).

Croatian media reported on the protests against the Istanbul Convention in Zagreb (2018) , whose messages are clearly illustrated by the slogans "Stop Istanbul Convention, for sovereign Croatia" and "Against the violence of the leftist NGOs". 7 In this context, violence against women (which is the focal point of the Istanbul Convention) was replaced with violence against the leftist NGOs which support the ratification of the Convention which would destabilize traditional Croatian values by introducing "gender ideology." By regarding language as a social practice, and uncovering the reproduction of social inequalities

\footnotetext{
${ }^{7}$ Maxportal.hr (2018): Protests against the Istanbul Convention in Zagreb, published 24 March 2018, https://www.maxportal.hr/vijesti/ulice-su-zakrcene-oko-20-tisuca-ljudi-na-prosvjedu-protiv-istanbulskekonvencije/ (accessed 5 February 2019).
} 
as well as the power relations in and over the discourse, it is possible to describe, interpret and explain the real meaning which is hidden in the text (Fairclough, 2001: 125). Concerning the main banner, Croatian sovereignty is conflated with Catholic dogma presenting the issue of the ratification as a threat to the Catholic moral integrity not on the individual level but as a moral threat to the whole nation (Martin, 2000: 78).

\subsection{The media and the myth of two equal sides}

Feminist NGO and women's organizations are tired of arguing that there is no such thing as "gender ideology" and that the Convention does not mention the rights of transgender people, but the public discourse has already been plagued by the invented scarecrow of "gender ideology." The Croatian Academy of Science and Arts issued a statement where they disparaged the Convention, claiming that it consists of "ideologically controversial formulations" and that "gender ideology is unacceptable for the Croatian educational system" (HINA, 2017). With these statements, they have further legitimized such discourse and blurred the differentiation between science and dogma. In turn, the Croatian Sociological Association issued a statement explaining the term "gender" and its sociological and historical scientific background, but the political power of the moral panic was too strong to be escaped. Alongside the ratification of the Convention, the Prime Minister and the Government issued an "interpretative statement", explaining that Croatia is not obligated to introduce "gender ideology" in its educational system. The CDA views discourse as a social practice and has an implicit political inclination towards advocacy for oppressed and discriminated groups by uncovering the power dynamics hidden in the discourse (Fairclough, 2001; Teun A Van Dijk, 2001; Wodak \& Krzyzanowski, 2008). Drawing upon that, the "interpretative statement" can be disseminated in two ways: as an acknowledgment and reproduction of the power that the idea of "gender ideology" has over the narrative concerning the Convention, and as a political strategy to please the anti-gender actors and the Church by legitimizing their power over the discourse. In both cases, the truly discriminated and oppressed groups in Croatia (such as minority groups, LGBT population, and victims of domestic and sexual violence) are effectively silenced. The media contributed greatly to the myth of two equal sides, by overrepresenting the religious activists' opinions and the Catholic Church attitudes, and by presenting all the opinions and attitudes as equally valuable and relevant. The liberal configuration of free speech allowed all kinds of opinions to proliferate in the public without any given measure to critically evaluate those opinions.

In the media debate ${ }^{8}$ on the issue of abortion, N1 Television decided to confront a gynaecologist, dr. Jasenka Grujić Koračin, and a Catholic activist, Katarina Kovačević. A Croatian newspaper (Jutarnji list, 2018) ${ }^{9}$ which reported on this TV duel presented the debate as having a clear-cut binary opposition: "For and Against". In the middle of the debate, while the gynaecologist was explaining the complexities of interdependence between the mother and the fetus, and the lack of scientific consensus on the beginning of life, the abortion opponent stated: "I am a layperson and I do not understand half of the things you said. The scientific things are not based on the truth." The gynecologist replied: "God's revelation is not

\footnotetext{
${ }^{8} \mathrm{~N} 1$ television, ,TNT abortion duel“, available at https://www.youtube.com/watch?v=Hve4kVle_5I, published on 30 September 2018

9 Jutarnji List (2018): Abortion Debate on N1 Television, published 30 Sept. 2018, available at https://www.jutarnji.hr/vijesti/hrvatska/protivnica-pobacaja-laik-sam-i-pola-stvari-vas-uopce-ne-razumijemznanstvene-stvari-nisu-temeljene-na-istini-ginekologinja-bozja-objava-nije-istina/7888650/(accessed 5.2. 2019).
} 
the truth." By presenting both sides as having a relevant opinion on the matter of abortion, the media contributed to the confusion among laypeople and the general public about science and scientific knowledge. In this case, even if $\mathrm{N} 1$ had confronted a religious gynecologist with a non-religious one, the issue at hand would still be the blurring of the difference between personal attitudes and religious standpoints (on the one hand) and scientific reasoning behind medical decisions and services (on the other hand). The fact that Croatia is a secular country, as defined in the Constitution, makes no bearing on the media's decision to heavily report on the opinions and statements of lay believers and clergy on social and political questions.

The myth of two equal sides has roots in the nation-stated building process and the historical revisionism. Since the $1990 \mathrm{~s}$, once marginal idea that the $\mathrm{NDH}^{10}$ and the Ustashe $^{11}$ regime was a valid claim for Croatian independence managed to find its way to the mainstream through right-wing historians, politicians, professors and writers, including the support of Catholic Church in Croatia. The relativization of the Ustashe crimes and insisting on the idea that Tito and the Communist Party in former Yugoslavia committed equal, if not bigger, atrocities can be seen in the continuous disputes over the number of victims in Jasenovac, a concentration camp in the region of Slavonia. It should come as no surprise that a recent research on the youth attitudes on radicalism shows that young people in Croatia consider that radical activities include conservative movements, such as those advocating for the abortion ban, as well as liberal movements' advocacy for gender and LGBT rights (Bačić, 2019); the researchers explain this stance by referring to the historical "equalization" (atonement and relativization) of the traditional ideological divide between the two historically opposed sides: the partisans and the ustashe.

In a similar way, violence against women is relativized in the media. After the initial public outrage against media reports, a woman's life is scrutinized to find an explanation for the violence she sustained, and her every statement or alleged interaction is under suspicion. In literature, it is designated as "the unrepresentability of trauma" (Kilby, 2007: 20 ) and the problem of interpreting a traumatic narrative from a non-survivor standpoint. In that sense, trauma-specific behaviour can be used as a weapon against the victims by raising suspicion about their credibility, which brings the exoneration of the perpetrators (Taylor, 2004: 264).

The myth about treacherous women who falsely report men still lurks somewhere in the collective consciousness. Taylor (2004: 258) explains that the relationship between the law and psychiatry is based on the Freud's family dysfunction theory which helped position children and women as fabricators of abuse and sexual provocateurs. Also, the cases of sexual and domestic violence are presented in the media as individual rather than structural and societal problems. For commercial media, the "shock value" from the reports on abuse and violence is a media commodity (Kilby, 2007: 119). Mainstream media naturalise inequality "by individualising social dysfunction and blaming the victims for their own alienation" (Richardson, 2007: 142). The history of repression and silencing women`s experiences of abuse and suffering is routinely repeated through patriarchal institutions and instruments. The public articulation of sexual violence comes at the expense of societal denunciation, rejection and even retaliation. As Taylor (2004: 284)

\footnotetext{
${ }^{10}$ Nezavisna Država Hrvatska NDH (the Independent State of Croatia) was a fascist puppet state of Italy and Germany established during the Second World War, responsible for the mass murder of Serbs, Jews, Roma and Croats who opposed the regime.

${ }^{11}$ The Ustashe was a Croatian fascist, racist, ultranationalist and terrorist organization that came to power in the NDH.
} 
derives from Goffman`s concept of "non-person" (1961), victims and survivors of sexual abuse can suffer from multiple forms of "social death" since they can be renounced by their family, community, professionals and the legal system.

\section{CONCLUSION}

In this paper, the author has tackled different but related issues. First, the paper provided a brief history and background of the new religious movements and their involvement in the process of retraditionalization. Croatia's (un)happy union with the Catholic Church was explained to emphasize the symbolic and actual power they had over the discourse on the ratification of the Istanbul Convention. In this paper and in the research, the author applied the critical discourse analysis (CDA) as a method and critical approach to analyze social problems, specifically retraditionalization and sexual violence, exploring them as a product of a historical and geopolitical context and revealing the power dynamics that contribute to the relativization of violence through discourse. To fully understand the scope and different needs and experiences of victims and survivors, there is a pressing need for a more systematic, qualitative as well as quantitative trauma-informed research on the issue of sexual violence. An ideal kind of research would focus on the socially constructed conditions of a neoliberal patriarchal culture which allows and reinforce abuse of women, as well as on proposing a radical tool for changing the social conditions in every area of women`s lives. There is also a pressing need for more qualitative research on the topic of new religious movements and their political influence on the de-secularization of the society through democratic means. These new conservative and religious movements in Croatia, as well as in other countries, pose a threat to gender equality and a challenge to the progressive politics of the left.

\section{REFERENCES}

Čengić, D. (1996). Privatisation and management buyout: The example of Croatia. Communist Economies and Economic Transformation, 8(4), 549-563.

Fairclough, N. (1995). Critical Discourse Analysis: The Critical Study of Language. Language in social life series (Vol. 81).

Fairclough, N. (2001). Critical discourse analysis as a method in social scientific research. In Methods of critical discourse analysis (pp. 121-138).

Fairclough, N. (2003). Textual analysis for social research. Routledge Taylor \& Francis Group.

Galić, B. (2018). A Case Study of Retraditionalization and Clericalization of the Croatian Society: "Feminist Threat" at the Governing Position of a Higer Education Institution. Ćasopis Sociologija, 44972(5), $272-497$.

Goffman, E. (1961). Asylums: Essays on the social situation of mental patients and other inmates. London: Penguin.

Hall, S. (1999). Race, the floating signifier. Media Education.

Kamenov, Z., \& Galić, B. (2011). Rodna ravnopravnost i diskriminacija u Hrvatskoj. Biblioteka ONA. Ured za Ravnopravnost spolova RH.

Kandiyoti, D. (1988). Bargaining with Patrirachy. Gender \& Society, 2(3), 274-290.

Kilby, J. (2007). Violence and the Cultural Politics of Trauma. Edinburgh: Edinburgh University Press Ltd.

Korolczuk, E., Graff, A. (2018). Gender as "Ebola from Brussels": The Anticolonial Frame and the Rise of Illiberal Populism. Signs: Journal Od Women in Culture and Society, 43(41), 797-821.

Kovats, E., \& Poim, M. (eds. . (2015). Gender as symbolic glue: the position and role of conservative and far right parties in the anti-gender mobilizations in Europe. (E. Kovats \& M. Poim, Eds.). Budapest: Foundation for European Progressive Studies, with the financial support of the European Parliament and by Friedrich-Ebert-Stiftung Budapest.

Kovats, E. (Ed.). (2017). The Future of the EU: Feminist perspectives from East-Central Europe. Budapest: Friedrich-Ebert-Stiftung Budapest. 
Lazar, M. M. (2005). Feminist critical discourse analysis: Gender, power and ideology in discourse. Palgrave Macmillan.

Luketic, K. (2013). Balkan: od geografije do fantazije. (Balkan: from geography to fantasy). Zagreb: Algoritam Zagreb.

Martin, Angela K. (2000). "Death of a Nation: Transnationalism, Bodies and Abortion in Late Twentiethcentury Ireland." In Gender Ironies of Nationalism: Sexing the Nation, edited by Tamar Mayer, 65-86. London and New York: Routledge.

Paternotte, D., \& Kuhar, R. (2017). Anti-Gender Campaigns in Europe: Mobilizing against Equality. (D. Paternotte \& R. Kuhar, Eds.). Rowman \& Littlefield International.

Peterson, V. S. (1999). Sexing Political Identities /Nationalism as Heterosexism. International Feminist Journal of Politics, 1(June), 34-65.

Richardson, E. J. (2007). Analysing Newspapers: an approach from critical discourse analysis. Palgrave Macmillan.

Taylor, S. C. (2004). Court-licensed abuse: patriarchal lore and the legal response to intrafamilial sexual abuse of children. P. Lang.

Todorova, M. (2009). Imagining the Balkans. Oxford University Press, 288

van Dijk, T. A. (1993). Principles of Critical Discourse Analysis. Discourse \& Society, 4(2), 249-283.

Van Dijk, Teun A. (2001). Critical discourse analysis. In The handbook of discourse analysis (pp. 352-371).

Wodak, R., Krzyzanowski, M. (2008). Qualitative Discourse Analysis in the Social Sciences. New York: Palgrave Macmillan.

\section{MEDIA SOURCES}

Bačić, M. (2019, February 9). Za mlade se radikalizam proteže od Željke Markić do LGBT prava. (Young people consider both Żeljka Markić and LGBT rights as radicalism/ young people see radicalism embodied both in entails ). Novosti. Retrieved from https://www.portalnovosti.com/za-mlade-se-radikalizam-protezeod-zeljke-markic-do-lgbt-prava?fbclid=IwAR1y5Uka9o4knvSkCF8t8qWO8oCs0t2nNgHJKidcSvDeyLwm4lFuxE61CU (accessed 5 February 2019).

Brakus, A. (2018, October 30). Poland's Hidden Hand Behind Croatian Catholic Lobby Group. Balkan Insight. Retrieved from http://www.balkaninsight.com/en/article/poland-s-hidden-hand-behind-croatian-catholiclobby-group-10-29-2018 (accessed 5 February 2019).

Dnevnik. hr (2018). Nadbiskup Barišić:"Isus Krist najveća je zaštita od nasilja u braku, obitelji i društvu" by Ma. B. (Bishop Barisic: Jesus Christ is the biggest protection against the violence in marriage, family and society). Dnevnik.hr, published 27 March 2018; available at: https://dnevnik.hr/vijesti/hrvatska/nadbiskupbarisic-isus-krist-najveca-je-zastita-od-nasilja-u-braku-obitelji-i-drustvu---511620.html (accessed 5 February 2019).

Golemac, S. (2016, August 12). 'Žene su danas neposlušne i uporno traže jednakost! One su drugotne, dok su muškarci prvotni!'('Today, women are disobedient and persistently seek equality! They are the other, while the men are the original') Jutarnji List, available at: https://www.jutarnji.hr/vijesti/hrvatska/zene-su-danasneposlusne-i-uporno-traze-jednakost-one-su-drugotne-dok-su-muskarci-prvotni/4609460/(accessed 5 February 2019).

HINA (2017, December 28). Akademici pisali Vladi, Saboru, Pantovčaku: Ovakvu Istanbulsku konvenciju ne ratificirati. (Academics write to the Government, Parliament, Pantovčak: This Istanbul Convention should not be ratified). Novi List, available at: http://www.novilist.hr/Vijesti/Hrvatska/Akademici-pisali-Vladi-SaboruPantovcaku-Ovakvu-Istanbulsku-konvenciju-ne-ratificirati?meta_refresh=true (accessed 5 February 2019).

Kovačević Barišić, R. (2018, March 12). Rodno utemeljeno nasilje vidi se u svakom sudskom spisu (Genderbased violence is visible in court files). Vecernji List, https://www.vecernji.hr/vijesti/rodno-utemeljenonasilje-vidi-se-u-svakom-sudskom-spisu-1231859 (accessed 5 February 2019)

Mrvoš Pavić, B. (2017, February 3) Ilegalne noćne pobačaje liječnici rade na račun bolnica, a naplaćuju ih po nekoliko tisuća kuna (Illegal nighttime abortions doctors perform on the hospital`s expense and charge then several thousands HRK). Novi List, available at: http://www.novilist.hr/Vijesti/Hrvatska/Ilegalne-nocnepobacaje-lijecnici-rade-na-racun-bolnica-a-naplacuju-ih-po-nekoliko-tisuca-kuna (accessed 5 February 2019).

N.C. (2018, March 24) Tisuće prosvjednika izviždalo Plenkovića uz povike 'Izdaja!' i 'Odlazi!': "Oprez, hrvatski moj narode, moglo bi nakon mrkve biti i batine" (Thousands of protestors whistled Plenković with outcries 'Treason!' and 'Leave!': „Caution, my Croatian people, after the carrot there might come the stick!“ Dnevnik.hr, available at: https://dnevnik.hr/vijesti/hrvatska/prosvjed-u-zagrebu-protiv-istanbulskekonvencije-krece-u-11-sati-ispred-hdz-a---511303.html (accessed 5 February 2019). 
Pavic, A. (2018, September 27). Udruga Željke Markić miješa se u sudske postupke po uzoru na bogatu američku Alijansu za obranu slobode. (Željka Markić's Association is interferring in court cases modeled on the rich American Alliance Defending Freedom) Faktograf. Retrieved from https://faktograf.hr/ 2018/09/27/udruga-zeljke-markic-mijesa-se-u-sudske-postupke-po-uzoru-na-bogatu-americku-alijansu-zaobranu-slobode/ (accessed 5 February 2019).

\section{WEBLINKS}

Croatian Central Bureau of Statistics, Women and Men in Croatia, 2018, www.dzs.hr/

Croatian Central Bureau of Statistics, population census of 2011, www.dzs.hr/

Jutarnji List (2018): Abortion Debate on N1 Television, published 30 Sept. 2018, available at https://www.jutarnji.hr/vijesti/hrvatska/protivnica-pobacaja-laik-sam-i-pola-stvari-vas-uopce-nerazumijem-znanstvene-stvari-nisu-temeljene-na-istini-ginekologinja-bozja-objava-nije-istina/7888650.

Maxportal.hr (2018): Protests against the Istanbul Convention in Zagreb, published 24 March 2018, https://www.maxportal.hr/vijesti/ulice-su-zakrcene-oko-20-tisuca-ljudi-na-prosvjedu-protiv-istanbulskekonvencije/ (accessed 5 February 2019).

N1 Television (2018): „TNT Abortion Duel”, published 30 Sept.2018, available at https://www.youtube.com/ watch?v=Hve4kVle_5I, )accessed 5 February 2019).

RTV B92 (2012): Zagreb: Protest against the EU, January 2012, available at https://www.youtube.com/ watch?v=dViCrTaTpBc/, (accessed 5 February 2019).

\section{SEKSUALNO NASILJE I NOVI OBLICI RELIGIOZNOG TRADICIONALIZMA U POST-KONFLIKTNOM HRVATSKOM POLITIČKOM KONTEKSTU}

Ovaj rad će se fokusirati na seksualno nasilje i nove oblike religioznog tradicionalizma koji se pojavljuju u hrvatskom političkom kontekstu i njihovu interpretaciju pojma roda. Kritična analiza diskursa kao metodološki okvir koristiti će se za istraživanje rasprava oko ratifikacije Istanbulske konvencije (Konvencije o sprečavanju i borbi protiv nasilja nad ženama i nasilja u obitelji) 2018. godine u Hrvatskoj. Religijske konzervativne organizacije počele su često koristiti pojam "rodne ideologije" kako bi stvorile strah, konfuziju i moralnu paniku u javnom diskursu vezano za ratifikaciju. Prema njihovim tumačenjima, "rodna ideologija" u Istanbulskoj konvenciji prokrijumčarena je kako bi se uništila tradicionalna hrvatska katolička heteroseksualna obitelj, omogućivši deci da sami biraju spol. Hrvatska je doživela značajne promene od raspada Jugoslavije devedesetih godina, odbacujući svoje socijalističko nasljeđe uz potporu Katoličke crkve i njezinu čvrstu antikomunističku retoriku koja nastoji poništiti bilo kakav napredak u smislu ravnopravnosti spolova postignutog tokom socijalizma. Istraživanje seksualnog nasilja iz intersekcijskog feminističkog okvira predstavlja izazov u klimi u kojoj je konzervativni diskurs preuzeo svaku raspravu o seksualnom nasilju u javnoj sferi osporavajući sam pojam roda čineći ga upitnom kategorijom društvene analize. Iako je Hrvatska ratificirala Istanbulsku konvenciju u travnju 2018. godine, Vlada je izdala "interpretativnu izjavu" dodatno legitimirajući pojam "rodne ideologije".

Ključne reči: seksualno nasilje, religiozni tradicionalizam, rodna ideologija 